DOI: 10.46340/eppd.2021.8.1.26

Ihor Nikolaienko

ORCID ID: https://orcid.org/0000-0002-3141-720X

Zaporizhzhia National University, Ukraine

\title{
FORMS AND METHODS OF PROTECTION \\ OF PASSENGERS' RIGHTS DURING \\ TRANSPORTATION IN URBAN \\ AND SUBURBAN COMMUNICATIONS
}

\section{Iгор Ніколаєнко \\ Запорізький національний університет, Україна \\ ФОРМИ ТА СПОСОБИ ЗАХИСТУ ПРАВ ПАСАЖИРА ПРИ ПЕРЕВЕЗЕННЯХ У МІСЬКОМУ ТА ПРИМІСЬКОМУ СПОЛУЧЕННІ}

Passenger transportation is an area of activity for various modes of transport. However, both the
organization of transportation and its implementation are dependent from many factors: the type
of transport and its peculiarities, the type of connection, the specific legal regulation of transport.
Transportation of passengers in urban and suburban traffic has its own peculiarities, as well as the
contracts they are formalized in. The specificity of the legal relationship for the carriage of passengers in urban and suburban traffic determines the dominant position of the carrier. This relationship is a public contract by its nature provided by the legislator in the case where one of the parties to the contract is a weak party that needs to secure its rights. Most of the terms of such an agreement are fixed in regulations. However, the acts of transport legislation governing the operation of urban road and urban electric transport do not have the consequences of a carrier's violation of its obligations or violation of a passenger's rights.

The impression is that the carrier is responsible, but there is the inability to protect the rights of the passenger. A passenger cannot force a carrier to pay a penalty in the event of a breach. This negates the grounds of contractual liability. However, the non-proprietary nature of the rights of the passenger does not exclude the possibility of their protection in the manner provided by Art. 16 of the Civil Code of Ukraine: recognition of the right; termination of the infringing action; restoration of the situation that existed before the violation; compulsory performance of duty in kind; change of legal relationship; termination of legal relationship; compensation for damages and other methods of compensation for property damage; compensation for moral (nonpecuniary) damage; the recognition of a decision, act or omission by a public authority. In general, the application of these means of protection is not limited and is determined by the nature of the violation and the ability of the method chosen to ensure the protection of the infringed passenger's right.

The choice of the method of protection is determined by the nature of the violation and its ability to provide protection.

Keywords: passenger, passenger transportation contract, urban transportation, protection of rights, methods of protection, forms of protection, compensation for damage, moral damage, concession

Постановка проблеми. Метою цивільно-правового регулювання є упорядкування суспільних відносин, їх стабільність та передбачуваність. Цій меті слугує і укладання цивільно-правових договорів, сторони яких прагнуть конкретизувати, пристосувати існуючий механізм цивільноправового регулювання до своїх потреб та інтересів в конкретних правовідносинах, персоналізуючи 
їх. Нормальною є ситуація належного виконання договору. Та, нажаль, сторона, зацікавлена в отриманні плати за договором, не особливо мотивована до цього, особливо коли йдеться про особу, яка використовує своє монопольне чи домінуюче положення на ринку послуг. Забезпечити права іншої сторони договору (в досліджуваному нами договору перевезення пасажира в міському та приміському сполученні) - пасажира, який $є$ споживачем транспортної послуги можливе шляхом створення умов для належного виконання договору перевізником. Йдеться і про організацію здійснення перевезення (шляхом ліцензування діяльності з перевезення пасажира, і про проведення конкурсів на обслуговування маршрутів в місцевому та приміському сполученні), і про нормативне закріплення наслідків неналежного виконання договору перевізником, і про застосування форм та способів захисту прав пасажира як способу здійснення особою ії права на захист. Іншими словами, йдеться і про профілактику правопорушення, і про вжиття заходів, спрямованих на відновлення порушеного права. Несприятливі наслідки для порушника, які узгоджуються із способами захисту прав пасажира мотивують до належного виконання перевізником договору перевезення.

Проаналізувавши реальний стан правовідносин з перевезення пасажира, нормативно-правові акти, якими врегульовані ці відносини, ми дійшли висновку, що останні містять «ідеальну» модель на рівні гіпотези та диспозиції правової норми, яка, на жаль, не містить а ні санкцій для перевізника на випадок порушення ним умов договору, а ні належного механізму захисту прав пасажира.

Відтак, варто виходити з загальних положень про наслідки неналежного виконання стороною умов договору та порядку, форм та способів захисту порушених прав особи, яка $є$ пасажиром. Однак, не всі 3 них можуть бути застосовані рівною мірою.

Тож ми поставили за мету визначити особливості застосування форм та способів захисту прав пасажира за договором перевезення пасажира в міському та приміському сполученні. Ця мета зумовлена необхідністю з'ясування рівня правової регламентації механізму захисту прав пасажира, визначення його ефективності, виявлення недоліків правового регулювання правовідносин в сфері захисту прав пасажира за договором перевезення пасажира в міському та приміському сполученні, внести пропозиції з удосконалення цього механізму.

Аналіз останніх досліджень з тематики. Дослідженням правовідносин 3 перевезення пасажирів, правовому регулюванню договірних правовідносин в цій сфері, забезпечення їх прав та їх захисту переймається незначна кількість науковців.

Серед останніх досліджень слід назвати роботи: У.П. Гришка, яка свої розвідки присвятила

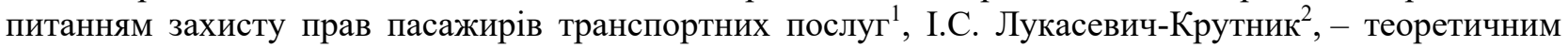
засадам правового регулювання договірних відносин з надання транспортних послуг у цивільному праві України, Г.В. Самойленко ${ }^{3},-$ вирішенню питань забезпечення прав пасажира. Проте, в силу наявних відмінностей в організації та способу виконання перевезень пасажирів різними видами транспорту та в різних сполученнях, означені дослідження мають узагальнюючий характер і не присвячені виключно перевезенням пасажирів у міському та приміському сполученні. Саме тому результати їх досліджень можуть бути використані лише почасти.

Системність порушень прав пасажирів у міському та приміському сполученні, відсутність ефективного механізму запобігання таким порушенням та усунення їх наслідків (захисту порушених прав), визначають потребу глибокого наукового осмислення причин таких порушень, недоліків правового регулювання та удосконалення механізму цивільно-правового захисту прав пасажирів. Останній має бути орієнтований на ефективність застосування порядку, форм та способів захисту порушених прав пасажира.

Основний виклад. В науковій літературі, присвяченій дослідженню правовідносин 3 перевезення пасажира, більшість науковців зосередили свою увагу на умовах договору (його змісті) та на особливостях цивільно-правової відповідальності перевізника. Парадоксально, але попри те, що договір укладається в інтересах пасажира, для задоволення його потреб і інтересів, традиційно з радянських часів основна увага приділена упорядкуванню правовідносин, орієнтованих

\footnotetext{
${ }^{1}$ Гришко У. П. (2017). Захист прав споживачів транспортних послуг: дисертачія на здобуття наукового ступеня кандидата юридичних наук. Івано-Франківськ: Державний вищий навчальний заклад «Прикарпатський Національний Університет імені Василя Стефаника» Навчально-науковий юридичний інститут.

2 Лукасевич-Крутник, I. С. (2019). Теоретичні засади правового регулювання договірних відносин з надання трансопртних послуг у иивільному праві України. Тернопіль: ФОП Паляниця В.А., 474.

${ }^{3}$ Самойленко, Г. В. (2020). Договір перевезення пасажира: теорія та практика забезпечення прав пасажира. Запоріжжя: Статус, 584.
} 
на забезпечення функціонування транспортної системи. Притому, упускалася мета такого регулювання, а забезпечення населення якісними транспортними послугами сприймалося як щось похідне від діяльності перевізника.

Такий підхід проявив себе як в законодавчій сфері, так, і в науковій (в підручниках з цивільного права ${ }^{1}$, спеціалізованих наукових дослідженнях ${ }^{2}$, наукових статтях), де основна увага приділялася не захисту прав пасажира, а цивільно-правовій відповідальності перевізника, яка повинна була виконувати попереджувальну та каральну функції, чим запобігати порушенню прав пасажира. На те в своїй роботі звернув увагу Г.В. Самойленко ${ }^{3}$.

У.П. Гришко зробила висновок, що основною метою форм відповідальності є забезпечення відновлення порушених прав споживачів транспортних послуг та гарантування захисту від подальших порушень ${ }^{4}$. Відшкодування збитків, як і відшкодування пасажирам моральної шкоди вона визначає як форму відповідальності за порушення прав споживачів транспортних послуг. Притому, вона визнає, що ці форми відповідальності перевізників є одночасно способами захисту прав пасажирів.

Г.В. Самойленко ${ }^{5}$ в своій монографії висловив позицію, що у цивільно-правової відповідальності та цивільно-правового захисту різне призначення, хоча вони і слугують одній меті. Такий підхід грунтується на аргументах Н.С. Кузнєцової, яка визначила, що і цивільно-правова відповідальність, і цивільно-правовий захист орієнтовані налокалізацію наслідків порушення суб'єктивних цивільних прав та мають спільну правозахисну мету ${ }^{6}$. Вона також дійшла висновку, що оскільки перелік способів захисту цивільних прав $є$ більш широким, аніж передбачені законом міри цивільно-правової відповідальності, то остання $є$ невід’ємною складовою цих способів.

Неможливо не погодитися з аргументами та висновками Я.В. П'янової ${ }^{7}$, що міри відповідальності виконують, в першу чергу, попереджувальну функцію, - i лише потім відновлювально-компенсаційну; міри захисту суб'єктивних прав же,- для досягнення відновлювально-компенсаційної мети. Н.С. Кузнєцова звернула увагу, що попри єдину правозахисну мету способи захисту за своїм об'ємом є більш широким поняттям, оскільки передбачають не лише відновлення порушеного права чи компенсацію втрат, але й попередження, припинення та усунення порушеного права ${ }^{8}$.

Такий підхід, загалом, прослідковується і в судовій практиці вирішення спорів, пов'язаних 3 порушенням прав пасажирів.

Так, в цивільній справі № 645/85/19 від 03.09.2019 р., яка розглядалася в Фрунзенському районному суді м. Харкова ${ }^{9}$ було встановлено, що позивач (пасажир, який має пільгу на безкоштовний проїзд) звернувся до відповідача АТ «Автотранспортне підприємство 16329», який здійснював обслуговування маршруту 20.02.2018 р. 3 м. Харкова до с. Липці. Пасажирові було відмовлено у його праві безкоштовного проїзду після 16.00 години. Відповідач відмову пояснив відсутністю фінансування у повному обсязі, внаслідок чого перевізник вирішив провозити пасажирів пільгової категорії безкоштовно з 9:00 до 16:00.

Суд вимоги позивача задовольнив, визнавши неправомірними дії приватного акціонерного товариства «Автотранспортне підприємство 16329» щодо відмови пасажирові-позивачу у пільговому перевезенні 20 лютого 2018 року.

\footnotetext{
${ }^{1}$ Шишка, Р. Б. (2015). Цивільне право Украӥни. Особлива частина. Київ: Видавництво Ліра-К, 653.

2 Лукасевич-Крутник, I. С. (2019). Теоретичні засади правового регулювання договірних відносин з надання трансопртних послуг у циивільному праві Украӥни. Тернопіль: ФОП Паляниця В.А., 366.

${ }^{3}$ Самойленко, Г. В. (2020). Договір перевезення пасажира: теорія та практика забезпечення прав пасажира. Запоріжжя: Статус, 33.

${ }^{4}$ Гришко, У. П. (2014). Окремі форми відповідальності перевізника як способи захисту прав споживачів транспортних послуг. Актуальні проблеми вдосконалення чинного законодавства Украӥни, 35, 66.

${ }^{5}$ Самойленко, Г. В. (2020). Договір перевезення пасажира: теорія та практика забезпечення прав пасажира. Запоріжжя: Статус, 29.

${ }^{6}$ Кузнєцова, Н. С. (2014). Вибрані праці. Київ: Юридична практика, 372-373.

${ }^{7}$ Спасибо-Фатєєва, І. В. (ред.) (2010). Цивільний кодекс України: науково-практичний коментар (пояснення, тлумачення, рекомендації з використанням позицій вищих судових інстанцій, Міністерства юстииії, науковців, фахівців). Харків : Колісник А. А., $1,175$.

${ }^{8}$ Кузнєцова, Н. С. (2014). Вибрані праці. Київ: Юридична практика, 372.

${ }^{9}$ Рішення у справі № 645/85/19, 2019 (Фрунзенський районний суд м. Харкова). Сдиний державний реєстр судових рімень $<$ http://reyestr.court.gov.ua/Review/84202732> (2020, вересень, 03).
} 
Право пасажира захищене. Негативні наслідки притягнення перевізника до цивільно-правової відповідальності відсутні.

Вважаємо, що захист цивільних прав пасажира $є$ первинним, в той час як притягнення перевізника-порушника до цивільно-правової відповідальності є вторинним, а по-суті, притягнення до такої відповідальності є одним із засобів захисту порушених прав. Йдеться про судовий порядок захисту прав пасажира, в т.ч. через притягнення перевізника до цивільно-правової відповідальності.

За визначенням О.В. Дзери, способами захисту є система активних заходів, які застосовуються суб'єктом цивільного права, компетентними органами держави, спрямованих на усунення порушень цивільного права чи інтересу, покладення виконання обов'язку з відновлення порушеного права на порушника ${ }^{1}$. Ним також визначено як загальні способи захисту цивільних прав, визначені ст. 16 ЦК України: 1) визнання права; 2) визнання правочину недійсним; 3) припинення дії, яка порушує право; 4) відновлення становища, яке існувало до порушення; 5) примусове виконання обов'язку в натурі; 6) зміна правовідношення; 7) припинення правовідношення; 8) відшкодування збитків та інші способи відшкодування майнової шкоди; 9) відшкодування моральної (немайнової) шкоди; 10) визнання незаконними рішення, дій чи бездіяльності органу державної влади, органу влади Автономної Республіки Крим або органу місцевого самоврядування, їхніх посадових і службових осіб та спеціальні, про що йдеться в ч. 2 ст. 16 ЦК України (суд може захистити цивільне право або інтерес іншим способом, що встановлений договором або законом чи судом у визначених законом випадках). О.В. Дзера також визначив, що вибір способів захисту зумовлюється також участю обмеженого кола осіб (наприклад, споживачів) чи визначається договором².

Проаналізувавши Закон України «Про Закон України «Про автомобільний транспорт» від 05.04.2001 p. ${ }^{3}$, Статут автомобільного транспорту УРСР, затверджений постановою Ради Міністрів УРСР 27.06.1969 p. ${ }^{4}$, Правила надання послуг пасажирського автомобільного транспорту, затверджені Постановою Кабінету Міністрів України від 18.02.1997 p. № $176^{5}$, Закон України «Про міський електричний транспорт» від 29.06.2004 р. ${ }^{6}$, Правила надання населенню послуг 3 перевезень міським електротранспортом: Постанова КМУ від 23.12.2004 р. № $1735^{7}$ нами встановлено, що чи не єдиним наслідком невиконання перевезення пасажира є можливість здійснення перевезення пасажира іншим транспортним засобом, чи повернення вартості квитка (грошей, сплачених за проїзд).

Звичайно, коли йдеться про порушення договірних умов, наслідком невиконання чи неналежного виконання договору є застосування договірної відповідальності (за підстав, визначених нормативно чи узгоджених сторонами договору). Проте, за договором перевезення пасажира у міському та приміському сполученні, який є публічним договором про приєднання, про договірну відповідальність особливо не йдеться, зважаючи як на правове положення пасажира, так і на зміст спеціалізованого транспортного законодавства.

Порушенням прав пасажира мали б відповідати наслідки, передбачені умовами договору, що визначені сторонами в договорі чи в актах транспортного законодавства. Проте, такі відсутні. Пунктом 43 Правил надання населенню послуг 3 перевезень міським електротранспортом лише передбачено, що права, обов'язки та відповідальність замовника і перевізника визначаються законом та договорами про організацію надання послуг з перевезень міським електричним транспортом,

\footnotetext{
${ }^{1}$ Дзера, О. В., Дзера, I. О. (2014). Способи захисту цивільних прав та інтересів у сучасному цивільному праві України. Актуальні проблеми приватного права Украӥни: збірник статей до ювілею доктора юридичних наук, професора Наталії Семенівни Кузнєиової. Київ: Юридична практика, 129.

${ }^{2}$ Там само, 132.

3 Закон про автомобільний транспорт, 105, 2001 (Верховна Рада України). Відомості Верховної Ради України, 22.

${ }^{4}$ Постанова про Статут автомобільного транспорту УРСР, 1969 (Рада Міністрів УРСР). Офіщійний сайт Верховної Ради Украӥни <http://zakon2.rada.gov.ua/laws/show/401-69-\%D0\%BF> (2020, вересень, 03).

${ }^{5}$ Постанова про затвердження Правил надання послуг пасажирського автомобільного транспорту № 176. 1997 (Кабінет Міністрів України). Офіційний сайт Верховної Ради України.

$<$ http://zakon2.rada.gov.ua/laws/show/176-97-\%D0\%BF> (2020, вересень, 03).

${ }^{6}$ Закон про міський електричний транспорт, 2004 (Верховна Рада України). Відомості Верховної Ради України, 51, 548.

${ }^{7}$ Постанова про затвердження Правил надання населенню послуг з перевезень міським електротранспортом, 2004 (Кабінет Міністрів України). Офіційний сайт Верховної Ради України

<https://zakon.rada.gov.ua/laws/show/1735-2004-\%D0\%BF> [in Ukrainian]. (2020, вересень, 03).
} 
укладеними на основі Типового договору про організацію надання транспортних послуг з перевезень міським електричним транспортом.

Правилами надання послуг пасажирського автомобільного транспорту закріплено права та обов'язки учасників правовідносин з перевезення пасажирів, проте, не наслідки їх порушення.

Саме тому науковцями, які досліджували особливості правового регулювання перевезень пасажирів робився висновок про обмежений характер відповідальності перевізника ${ }^{1}$.

Неустойка, яка $\epsilon$ одним із способів забезпечення виконання зобов'язань і інструментом цивільно-правової відповідальності, не застосовується з тих же причин: 1) відсутність можливості пасажира за договором перевезення пасажира у міському та приміському сполученні за свого «слабкого» правового положення визначати умови публічного договору (ч. 2 ст. 915 ЦК України визначено, що договір перевезення транспортом загального користування $є$ публічним договором) у відповідності до принципу свободи договору; 2) відсутність передбачених законом санкцій у якості наслідків порушення договірних умов перевізником.

Проаналізувавши Закон України «Про захист прав споживачів», який застосовується i до правовідносин 3 перевезень пасажирів, щоправда, в частині, не врегульованій транспортним законодавством, ми виявили лише окремі з запропонованих ст. 16 ЦК України способи цивільноправового захисту: відшкодування збитків та моральної шкоди, припинення дії, яка порушує право, примусове виконання обов'язку в натурі, припинення правовідношення. Водночас, законодавство не заперечує i не обмежує застосування інших способів. Це пояснюється закріпленням ст. 55 Конституції України права особи на захист, зокрема, правом будь-якими не забороненими законом засобами захищати свої права і свободи від порушень і протиправних посягань.

Статтею 928 ЦК України закріплено відповідальність перевізника за шкоду, завдану каліцтвом, іншим ушкодженням здоров'я або смертю пасажира. Згідно ії положень перевізник притягується до цивільно-правової відповідальності відповідно до положень Глави 82 цього Кодексу, якщо договором або законом не встановлена відповідальність перевізника без вини. Така підстава цивільноправової відповідальності $є$ не договірною, а деліктною відповідальністю (з завдання шкоди), попри те, що така шкода і пов'язана та зумовлена у якості наслідку діяльності перевізника. Вона відповідає відшкодуванню майнової шкоди як одного із способів захисту порушених цивільних прав.

В своїй монографії Г.В. Самойленко ${ }^{2}$ визначив, що вибір постраждалою особою-пасажиром у перевезеннях в міському та приміському сполученнях, способів захисту порушених прав, як передбачених ст. 16 ЦК України, так і інших способів, має визначатися двома критеріями: характером самого порушення та властивістю і спроможністю відповідного способу захисту досягнути мети захисту. Притому, він визначив обмеженість застосування конструкції «договірної відповідальності» положеннями спеціалізованих актів транспортного законодавства, яке не передбачає наслідків порушення умов договору перевізником-порушником, та, вибору відповідного способу захисту пасажиром, права якого порушено.

Цей приклад сприяє у вирішенні існуючого в науці спору щодо розмежування «договірної відповідальності» від «відповідальності за договором», де перша $\epsilon$ проявом саморегулювання, а друга, - негативних наслідків для порушника, які можуть бути визначені як нормативно, так і сторонами за договором.

Більшість науковців, які проводили дослідження правовідносин з перевезення пасажирів, звертали увагу, що вони є споживчими за своєю природою, що зумовлює застосування до них положень Закону України «Про захист прав споживачів».

Самойленко Г.В., Резніченко С.В. та Нечипуренко О.М. звернули увагу, що в п. 2 Постанови Пленуму Верховного Суду України «Про практику розгляду цивільних справ за позовами про захист прав споживачів» № 5 від 12.04.1996 р. прямо закріплено, що дія закону поширюється на відносини 3 перевезень громадян, а п. 3 визначив пріоритетність дії положень Закону України «Про захист прав споживачів» 3 тих питань, щодо яких існує конкуренція Закону та спеціального законодавства ${ }^{3}$.

\footnotetext{
${ }^{1}$ Шишка, Р. Б. (2015). Цивільне право України. Особлива частина. Київ: Видавництво Ліра-К, 657; Нечипуренко, О. М., Резніченко, С. В., Самойленко, Г. В. (2010). Цивільно-правове регулювання перевезень пасажирів таксі. Одеса: ОДУВС, 188.

${ }^{2}$ Самойленко, Г. В. (2020). Договір перевезення пасажира: теорія та практика забезпечення прав пасажира. Запоріжжя: Статус, 486.

${ }^{3}$ Нечипуренко, О. М., Резніченко, С. В., Самойленко, Г. В. (2010). Цивільно-правове регулювання перевезень пасажирів таксі. Одеса: ОДУВС, 159.
} 
В свою чергу А.О. Мінченко визначив, що попри посилання на норми даних актів, воно обмежується лише деякими загальними нормами, в яких йдеться про обов'язок перевізника своєчасно перевезти пасажира від пункту виїзду до пункту призначення, вказаного в проїзному документі, а також на право споживача на належну якість обслуговування. Питання розміру відповідальності в жодному з зазначених актів не вирішується ${ }^{1}$.

C.В. Резніченко та О.М. Нечипуренко ставили питання щодо правомірності обмеження відповідальності перевізника за невиконання або неналежне виконання зобов'язань, що випливають із договору перевезення пасажира. Вони виходили з положень Закону України «Про захист прав споживачів», згідно якого збитки, заподіяні споживачеві, підлягають відшкодуванню в повній сумі понад неустойку, установлену законом або договором ${ }^{2}$. В свою чергу, Г.В. Самойленко звернув увагу, що, здебільшого, при порушенні договору перевезення пасажира не йдеться про матеріальну шкоду, тим не менше, право пасажира є порушеним і потребує захисту³.

Судова практика застосування транспортного законодавства та Закону України «Про захист прав споживачів» свідчить, що відшкодування завданих збитків та компенсація моральної шкоди $є$ чи не єдиними способами захисту прав пасажирів у перевезеннях міським та приміським транспортом, тобто, таким, що здійснює перевезення у міському та приміському сполученні.

Захист порушених прав пасажира за договором перевезення пасажира у міському та приміському сполученні можливий в юрисдикційній та неюрисдикційній формі. Притому, юрисдикційна форма має, щонайменше два порядки захисту: адміністративний та судовий. Визнаємо, що судовий $є$ найбільш ефективним з точки зору примусової сили судового рішення. Водночас, адміністративний порядок, будучи важелем впливу на перевізника, $\epsilon$ не менш ефективним 3 точки зору можливих негативних наслідків для перевізника-порушника (призупинення чи анулювання дії ліцензії, дозволу на обслуговування маршруту, тощо). Він мотивує перевізника значно більше на задоволення вимог пасажира, права якого порушено, хоча більше орієнтований на недопущення порушень в майбутньому.

Стосовно вибору пасажиром форми захисту свого порушеного права, висловлюємо позицію, що з-поміж двох існуючих форм захисту цивільних прав: юрисдикційної та неюрисдикційної, найбільш ефективною є юрисдикційна, як така, що забезпечена можливістю застосування державного примусу. Проте, застосування неюрисдикційної форми захисту (самозахисту) чи претензійного порядку ${ }^{4}$ може бути не менш ефективним, швидким та матеріально не обтяжливим у порівнянні 3 юрисдикційним судовим порядком захисту порушеного права.

Загалом, транспортне законодавство України орієнтоване на застосування претензійного порядку вирішення спорів, в тому числі виникаючих між перевізником та пасажиром. Проте, обов'язковість дотримання претензійного порядку вирішення спорів наразі нівельовано безпосередністю здійснення особою права на судовий захист своїх порушених, оспорюваних чи невизнаних прав.

Вважаємо, що досудовий (претензійний) порядок вирішення спорів між перевізниками та пасажирами має свої переваги у порівнянні з судовим порядком. Такими є: можливість негайного вирішення конфлікту; прояв розумності, добросовісності та справедливості (поінформованості перевізника-порушника як прояву партнерських відносин); результат вирішення претензії пасажира може засвідчити факт наявності спору між сторонами договору, що $є$ важливим, оскільки на суди покладено вирішення цивільно-правових спорів (що, водночас, не заперечує компетенції суду здійснювати захист цивільних прав у випадку їх порушення); дозволяє уникнути надмірного формалізму.

Висновки. Цивільно-правовий захист прав пасажирів за перевезеннями у міському та приміському сполученні має особливості і зумовлений рядом чинників: 1) детермінований

\footnotetext{
${ }^{1}$ Мінченко, А. О. (2011). Договір перевезення пасажира та багажу залізничним транспортом в Україні: дисертація на здобуття наукового ступеня кандидата юридичних наук. Київ: Національний Університет Внутрішніх Справ, 161.

${ }^{2}$ Нечипуренко, О. М., Резніченко, С. В., Самойленко, Г. В. (2010). Цивільно-правове регулювання перевезень пасажирів таксі. Одеса: ОДУВС, 159.

${ }^{3}$ Самойленко, Г. В. (2019). Права пасажира: новітні цивілізаційні підходи та забезпечення. ScienceRise: Juridical Science, 4 (10), 29.

${ }^{4}$ Самойленко, Г. В. (2020). Договір перевезення пасажира: теорія та практика забезпечення прав пасажира. Запоріжжя: Статус, 465.
} 
специфікою перевезень у міському та приміському сполученні; 2) детермінований положеннями актів транспортного законодавства та Закону України «Про захист прав споживачів»; 3) вибір форм захисту має ініціативний та диспозитивний характер, визначається оцінкою постраждалого пасажира здатністю цієї форми забезпечити такий захист; 4) претензійний порядок захисту прав пасажира $€$ одним із варіантів здійснення ним самозахисту (без вдавання до звернення до державних органів); 5) публічний характер договору перевезення пасажира громадським транспортом як транспортом загального користування виключає застосування неустойки як засобу договірної відповідальності; 6) основними способами захисту прав пасажира у перевезеннях у міському та приміському сполученні $є$ відшкодування завданих збитків та компенсація моральної шкоди; 7) застосування способів захисту цивільних прав, закріплених ст. 16 ЦК України не обмежене і визначається характером порушення і спроможністю обраного способу забезпечити захист порушеного права пасажира.

\section{References:}

1. Grishko, U. P. (2017). Zakhyst prav spozhyvachiv transportnykh posluh [Protection of the rights of consumers of transport services]: dysertatsiia kandydata yurydychnykh nauk [the dissertation of the candidate of legal sciences]. Ivano-Frankivsk: Vasyl Stefanyk Precarpathian National University State Higher Educational Institution Educational and Scientific Law Institute . [in Ukrainian].

2. Lukasevich-Krutnik, I. S. (2019). Teoretychni zasady pravovoho rehuliuvannia dohovirnykh vidnosyn z nadannia transoprtnykh posluh u tsyvilnomu pravi Ukrainy [Theoretical bases of legal regulation of contractual relations on rendering of transport services in civil law of Ukraine]. Ternopil: FOP Palianytsia, V. A. [in Ukrainian].

3. Samoylenko, G. V. (2020). Dohovir perevezennia pasazhyra: teoriia ta praktyka zabezpechennia prav pasazhyra [Passenger transportation contract: theory and practice of ensuring passenger rights]. Zaporizhzhia: Status. [in Ukrainian].

4. Shyshka, R. B. (2015). Tsyvilne pravo Ukrainy. Osoblyva chastyna [Civil law of Ukraine. A special part]. Kyiv: Lira-K. [in Ukrainian].

5. Grishko, U. P. (2014). Okremi formy vidpovidalnosti pereviznyka yak sposoby zakhystu prav spozhyvachiv transportnykh posluh [Some forms of carrier liability as a way to protect the rights of consumers of transport services]. Aktualni problemy vdoskonalennia chynnoho zakonodavstva Ukrainy [Current problems of improving the current legislation of Ukraine]. [in Ukrainian].

6. Kuznetsova, N. S. (2014). Vybrani pratsi [Selected works]. Kyiv: Yurydychna praktyka. [in Ukrainian].

7. Spasybo-Fatyeyeva, I. V. (ed.) (2010).Tsyvilnyi kodeks Ukrainy: naukovo-praktychnyi komentar (poiasnennia, tlumachennia, rekomendatsii z vykorystanniam pozytsii vyshchykh sudovykh instantsii, Ministerstva yustytsii, naukovtsiv, fakhivtsiv). Zahalni polozhennia [Civil Code of Ukraine: scientific and practical commentary (explanations, interpretations, recommendations using the positions of higher courts, the Ministry of Justice, scientists, experts). General provisions]. Kharkiv: Kolisnyk A.A. [in Ukrainian].

8. Rishennia u spravi № 645/85/19, 2019 (Frunzenskij raionnij sud m. Kharkova) [Decision in case № 645/85/19, 2019 (The Frunzensky District Court of Kharkiv)]. Yedynyy derzhavnyy reyestr sudovykh rishen [Unified state register of court decisions] <http://reyestr.court.gov.ua/Review/84202732>(2020, September, 03). [in Ukrainian].

9. Dzera, O.V., Dzera, I.O. (2014). Sposoby zakhystu tsyvilnykh prav ta interesiv u suchasnomu tsyvilnomu pravi Ukrainy [Methods of protection of civil rights and interests in modern civil law of Ukraine]. Aktualni problemy pryvatnoho prava Ukrainy: zbirnyk statei do yuvileiu doktora yurydychnykh nauk, profesora Natalii Semenivny Kuznietsovoi [Actual problems of private law of Ukraine: a collection of articles to the anniversary of Doctor of Law, Professor Natalia Kuznetsova]. Kyiv: Jurydychna praktyka. [in Ukrainian].

10. Zakon pro avtomobilnyi transport, 2001 (Verkhovna Rada Ukrainy). [Law on Road Transport, 2001 (Verkhovna Rada of Ukraine)]. Vidomosti Verkhovnoi Rady Ukrainy [Information of the Verkhovna Rada of Ukraine], 22. [in Ukrainian].

11. Postanova pro Statut avtomobilnoho transportu URSR, 1969 (Rada Ministriv URSR). [Resolution on the Charter of Road Transport of the USSR, 1969 (Council of Ministers of the USSR)]. Ofitsiinyi sait Verkhovnoi Rady Ukrainy [Official site of the Verkhovna Rada of Ukraine <http://zakon2.rada.gov.ua/laws/show/401-69-\%D0\%BF> (2020, September, 03). [in Ukrainian].

12. Postanova pro zatverdzhennia Pravyl nadannia posluh pasazhyrskoho avtomobilnoho transportu, 1997 (Kabinet Ministriv Ukrainy). [Resolution on approval of the Rules for the provision of passenger road transport services № 176. 1997 (Cabinet of Ministers of Ukraine)]. Ofitsiinyi sait Verkhovnoi Rady Ukrainy [Official site of the Verkhovna Rada of Ukraine] <http://zakon2.rada.gov.ua/laws/show/176-97-\%D0\%BF> (2020, September, 03). [in Ukrainian].

13. Zakon pro miskyi elektrychnyi transport, 2004 (Verkhovna Rada Ukrainy). [Law on Urban Electric Transport 2004 (Verkhovna Rada of Ukraine)]. Vidomosti Verkhovnoi Rady Ukrainy [Information of the Verkhovna Rada of Ukraine] <http://zakon2.rada.gov.ua/laws/show/176-97-\%D0\%BF> (2020, September, 03). [in Ukrainian]. 
14. Postanova pro zatverdzhennia Pravyl nadannia naselenniu posluh z perevezen miskym elektrotransportom, 2004 (Kabinet Ministriv Ukrainy). [Resolution on approval of the Rules for the provision of public transport services to the population, 2004 (Cabinet of Ministers of Ukraine)]. Ofitsiinyi sait Verkhovnoi Rady Ukrainy [Official site of the Verkhovna Rada of Ukraine] <https://zakon.rada.gov.ua/laws/show/1735-2004-\%D0\%BF> (2020, September, 03). [in Ukrainian].

15. Minchenko, A. O. (2011). Dohovir perevezennya pasazhyra ta bahazhu zaliznychnym transportom v Ukrayini [Contract for the carriage of passengers and luggage by rail in Ukraine]: dysertatsiya na zdobuttya naukovoho stupenya kandydata yurydychnykh nauk [the dissertation for the degree of Candidate of Law]. Kyiv: National University of Internal Affairs. [in Ukrainian].

16. Nechypurenko, O. M., Reznichenko, S. V., Samoylenko, G. V. (2010). Tsyvilno-pravove rehuliuvannia perevezen pasazhyriv taksi [Civil law regulation of taxi passengers: a monograph]. Odesa : ODUVS. [in Ukrainian].

17. Samoylenko, G. V. (2019). Prava pasazhyra: novitni tsyvilizatsiini pidkhody ta zabezpechennia [Passenger rights: the latest civilizational approaches and support]. ScienceRise: Juridical Science, 4. [in Ukrainian]. 